\title{
UK universities in bed with the military
}

Universities in the United Kingdom may be doing far more research for the military than official estimates acknowledge, according to a report released last week.

Scientists for Global Responsibility (SGR), a Folkestone-based group that campaigns against military spending, says that of 13 universities surveyed, 12 received an average of around $£ 2.4$ million (US $\$ 4.7$ million) each to conduct military and security-related research between 2005 and 2006 . Some received as much as $£ 5$ million. The figures contrast sharply with SGR's estimate of an average of $£ 400,000$ per UK university based on the official 2004 figure of a total of $£ 44$ million defence-related research grants across all UK universities. "Our analysis leads us to ask whether government statistics in this area are as reliable as they should be," the study says.

In many cases the money came from both government and commercial sources. Defence firms, including UK-based BAE Systems, Rolls Royce and QinetiQ and US-based Lockheed
Martin, make significant contributions to university funding. Most of the money goes to engineering and the physical sciences. In addition, the University of Cambridge, which publishes information on its funding sources,

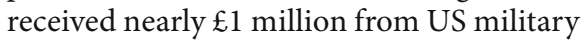
organizations. Accurate estimates for US government funding at other UK institutions could not be obtained.

The lack of cooperation by university officials during the study was as disturbing as the actual figures, says Chris Langley, a consultant for SGR, who compiled the report with his colleagues. Vice-chancellors and other senior university personnel refused to speak about the money, and researchers receiving military funding were half as likely to respond to the group's survey compared with other researchers, he says. "We found a huge amount of reluctance." Langley says that he would like to see "safeguards and standards" that would help regulate university money coming from defence sources.
"We do not accept the claim that universities are insufficiently accountable," counters Rick Trainor, president of Universities UK, which represents 132 universities. "Staff and students within universities are expected to adhere to the highest standards of conduct and ethical behaviour in research," he adds.

Langley says that ultimately he believes higher education should spend less on improving the UK's weapons technology and more on research of benefit to society: "We have our priorities wrong," he says.

The Ministry of Defence (MOD) did not comment on the figures, but says it is actively broadening its science and technology supplier base. "MOD is actively seeking to make access to the $\mathfrak{E 5 0 0}$ million a year research budget easier for universities," a spokesperson told Nature, adding that there will be further incentives for "academia to engage with the MOD and the established defence industry".

Geoff Brumfiel 